\title{
Effect of vitamin D supplementation on bone and vitamin D status among Pakistani immigrants in Denmark: a randomised double-blinded placebo-controlled intervention study
}

\author{
Rikke Andersen $^{1 *}$, Christian Mølgaard ${ }^{2}$, Lene T. Skovgaard ${ }^{3},{\text { Christine } \text { Brot }^{1} \text {, Kevin D. Cashman }}^{4}$, \\ Jette Jakobsen ${ }^{5}$, Christel Lamberg-Allardt ${ }^{6}$ and Lars Ovesen ${ }^{1}$ \\ ${ }^{1}$ Department of Nutrition, National Food Institute, Technical University of Denmark, Mфrkhфj Bygade 19, \\ DK-2860 Sфborg, Denmark \\ ${ }^{2}$ Department of Human Nutrition, Faculty of Life Sciences, University of Copenhagen, Copenhagen, Denmark \\ ${ }^{3}$ Department of Biostatistics, University of Copenhagen, Copenhagen, Denmark \\ ${ }^{4}$ Department of Food and Nutritional Sciences, University College Cork, Cork, Republic of Ireland \\ ${ }^{5}$ Department of Chemistry, National Food Institute, Technical University of Denmark, S $\phi b o r g$, Denmark \\ ${ }^{6}$ Division of Nutrition, University of Helsinki, Helsinki, Finland \\ (Received 3 April 2007 - Revised 8 November 2007 - Accepted 8 November 2007 - First published online 22 January 2008)
}

Severe vitamin D deficiency is common among Muslim immigrants. The dose necessary to correct the deficiency and its consequence for bone health are not known for immigrants. The aim was to assess the effect of relatively low dosages of supplemental vitamin $\mathrm{D}$ on vitamin $\mathrm{D}$ and bone status in Pakistani immigrants. This 1-year-long randomised double-blinded placebo-controlled intervention with vitamin $\mathrm{D}_{3}(10 \mathrm{and} 20 \mu \mathrm{g} / \mathrm{d})$ included girls (10.1-14.7 years), women (18.1-52.7 years) and men (17.9-63.5 years) of Pakistani origin living in Denmark. The main endpoints were serum 25-hydroxyvitamin D (S-25OHD), parathyroid hormone, bone turnover markers and bone mass. The study showed that supplementation with 10 and $20 \mu \mathrm{g}$ vitamin $\mathrm{D}_{3}$ per d increased S-25OHD concentrations similarly in vitamin D-deficient Pakistani women (4-fold), and that $10 \mu \mathrm{g}$ increased S-25OHD concentrations 2-fold and $20 \mu \mathrm{g}$ 3-fold in Pakistani men. S-25OHD concentrations increased at 6 months and were stable thereafter. Baseline S-25OHD concentrations tended to be lower in girls and women than in men; females achieved about $46 \mathrm{nmol} / \mathrm{l}$ and men $55 \mathrm{nmol} / 1$ after supplementation. Serum intact parathyroid hormone concentrations decreased at 6 months, but there was no significant effect of the intervention on bone turnover markers and dual-energy X-ray absorptiometry measurements of the whole body and lumbar spine.

Randomised controlled trials: Vitamin D intervention: Pakistani immigrants: Bone turnover: Bone mass

The large population groups living in a traditional Islamic cultural pattern in Europe are at major risk of vitamin D deficiency due to insufficient sun exposure and low vitamin D intake. Previously, in the cross-sectional part of this study, we found median 25-hydroxyvitamin D (25OHD) concentrations between 10.9 and $20.7 \mathrm{nmol} / \mathrm{l}$ among adolescent girls, premenopausal women and men with Pakistani origin living in Denmark ${ }^{(1)}$. Similar results have been reported in Norway ${ }^{(2-5)}$ and in the $\mathrm{UK}^{(6)}$.

Clinical trials investigating the effect of vitamin D supplementation on fracture risk have shown conflicting results $^{(7-12)}$. Several of the trials combined $\mathrm{Ca}$ with vitamin $\mathrm{D}$, making it unclear which nutrient is responsible for an observed effect. However, trials with vitamin D supplementation alone (dosages $10-20 \mu \mathrm{g} / \mathrm{d}$ ) also find conflicting results $^{(10,11,13,14)}$. A meta-analysis of seven randomised trials found that fracture risk was reduced among ambulatory or institutionalised elderly individuals at vitamin D supplemental dosages of $17 \cdot 5-20 \mu \mathrm{g} / \mathrm{d}$, but not at $10 \mu \mathrm{g} / \mathrm{d}^{(15)}$. However, this differs from a Cochrane review, which found fracture reduction among elderly institutionalised individuals given vitamin $\mathrm{D}$ and $\mathrm{Ca}$, but the effect of vitamin $\mathrm{D}$ alone was unclear $^{(16)}$. Bone mineral density (BMD) is a useful measure for predicting fracture risk $^{(17,18)}$, and BMD was increased with vitamin $\mathrm{D}$ and $\mathrm{Ca}$ supplementation in some studies among elderly Caucasians ${ }^{(7-9)}$ and with vitamin D supplementation alone in other studies ${ }^{(19-21)}$.

Case reports show improvement in vitamin D status (and reduced muscle pain) by vitamin $\mathrm{D}$ supplementation among immigrants ${ }^{(22,23)}$; however, very few vitamin D intervention studies have been performed with ethnic groups other than Caucasians from Western countries. In a small group of vitamin D-depleted Asians in the UK, treatment with vitamin $D$ increased their vitamin D status ${ }^{(24)}$. Several surveys

Abbreviations: BA, bone area; BMC, bone mineral content; BMD, bone mineral density; DXA, dual-energy X-ray absorptiometry; GLM, general linear model;

MIXED, mixed linear model; 25OHD, 25-hydroxyvitamin D; S-25OHD, serum 25-hydroxyvitamin D; S-iPTH, serum intact parathyroid hormone.

* Corresponding author: Dr Rikke Andersen, fax +45 723471 19, email ria@food.dtu.dk 
investigated the Asian community in Glasgow during the 1960-80s, and about $10 \mu \mathrm{g}$ vitamin D/d seemed to prevent rickets and osteomalacia ${ }^{(25-29)}$. Vitamin D-fortified chapatti flour was uniformly effective in increasing $25 \mathrm{OHD}$ concentrations as vitamin D capsules ${ }^{(25)}$. In a study from Norway where Pakistani women were advised to take vitamin D supplements, no improvement in status was shown after 1 year, but whether the advice was followed was not known ${ }^{(3)}$. A randomised controlled trial of vitamin D supplementation in Ca-replete African-American women did not observe an effect on bone loss or bone turnover markers ${ }^{(30)}$.

The purpose of the present study was to assess the effect of relatively low dosages of supplemental vitamin $\mathrm{D}$ on vitamin $\mathrm{D}$ status in an immigrant group where sun exposure and vitamin D intake is minimal, and to assess the effect of vitamin D supplementation on bone turnover and bone mass in this group. The main endpoints were serum 25-OHD (S-25OHD), serum intact parathyroid hormone ( $\mathrm{S}-\mathrm{iPTH})$, and markers for bone turnover and bone mass. The relatively low dosages (the recommended daily intake and twice the recommended daily intake for this population group) used in the present study were chosen with a view to the possibility of fortification.

\section{Subjects and methods}

\section{Study design}

The study was a 1-year-long randomised double-blinded placebo-controlled intervention study with two doses of vitamin $D_{3}(10$ and $20 \mu \mathrm{g} / \mathrm{d})$. The subjects were seen three times during the year, at months 0,6 and 12. The main endpoints were S-25OHD, S-iPTH, bone turnover markers and markers of bone mass (whole-body and lumbar spine bone area (BA), BMD and bone mineral content (BMC)).

The local ethics committee (registration no. KA01139gs) and the Danish Medicines Agency (a tablet containing $20 \mu \mathrm{g}$ vitamin $\mathrm{D}_{3}$ is considered as a drug and not a supplement in Denmark) (registration no. 2612-1805) approved the study protocol. The study was carried out in accordance with the Declaration of Helsinki. Written informed consent was obtained from all participants, as well as from the parents or guardians of the girls.

\section{Subjects}

Subjects were recruited through information meetings at schools, mosques, cricket clubs, private organisations, etc, adverts in local Pakistani newspapers, local Pakistani radio and television, and posters in relevant places, since the Danish National Central Offices of Civil Registrations do not contain information about ethnic origin. Consequently, the sample was not random and the representativeness of the sample could not be assessed due to lack of information about non-acceptors. The subjects were included from January 2002 to November 2002.

Subjects included were adolescent girls (median age 12.2 years; range $10 \cdot 1-14.7$ years), women (median age 36.2 years; range 18.1-52.7 years) and men (median age 38.3 years; range 17.9-63.5 years). All subjects were of Pakistani origin (immigrants or descendants with Pakistani parents) primarily living in the Copenhagen area, Denmark (latitude $\left.55^{\circ} \mathrm{N}\right)$. About $87 \%$ of the 19250 individuals with Pakistani origin (immigrants and descendants) in Denmark live in the Copenhagen area ${ }^{(31)}$. The baseline S-25OHD status and the determinants of vitamin D status (for example, clothing, sun and smoking habits) were investigated earlier ${ }^{(1)}$.

Among the 247 subjects participating in the first visit, 199 (twenty-six girls, eighty-nine women and eighty-four men) were willing to be included in the intervention study (month $0)$. Twenty-two girls, sixty-five women and sixty-nine men participated in the second visit at month 6. Twenty-one girls, sixty-two women and sixty-five men were seen at month 12, and thus completed the study (the overall dropout rate at the end of the study was $26 \%$, and 19, 30 and $23 \%$ for girls, women and men, respectively).

The goal was to recruit sixty girls, sixty women, and sixty men, i.e. twenty girls, twenty women and twenty men in each of the three treatment groups (this number would be able to detect a change in BMD of the same size as the population standard deviation, $0.025 \mathrm{~g} / \mathrm{cm}^{2}$, i.e. a change of $1 \mathrm{SD}$ (provided significance level $5 \%$, power $85 \%$ )).

Exclusion criteria were medications known to affect bone metabolism or S-25OHD concentrations (anti-epileptics, active vitamin D metabolites, corticosteroids, thyroid hormones, bisphosphonates, oestrogens), serious illness (for example, cancer, or liver or kidney insufficiency), pregnancy, planning pregnancy within 1 year, breast-feeding, and serum ionised $\mathrm{Ca}$ concentrations $>1.5 \mathrm{mmol} / \mathrm{l}$.

The women were tested for pregnancy before dual-energy X-ray absorptiometry (DXA) scanning. Subjects with incomplete data in one or more of the explanatory variables were excluded in the multiple regression analyses, and they did not differ significantly from the study population with respect to $\mathrm{S}-25 \mathrm{OHD}$ and the available explanatory variables.

\section{Tablets}

Scanpharm A/S (Birkerød, Denmark) produced the placebo (cellulosum microcristallium) and vitamin $\mathrm{D}_{3}(10$ and $20 \mu \mathrm{g})$ tablets especially for the present study without using any pig-containing substances. Scanpharm A/S delivered the three kinds of tablets in coded boxes. The subjects (girls, women and men separately) were randomised (by an impartial scientist) in blocks of six using random numbers.

At the first visit, 3 months' consumption of tablets were handed out, the next 3 months' consumption were sent by mail to the subjects, and at the second visit the remaining 6 months' consumption of tablets were handed out. The subjects were instructed to bring back any remaining tablets at the second and third visit, and the compliance was calculated by tablet counting. The median compliance was 85 (range 43-100), 92 (42-115) and $93(33-105) \%$ for girls, women and men, respectively.

\section{Sampling and analyses of biochemical parameters}

Blood samples were taken between 07.30 and 10.30 hours at all three visits (months 0,6 and 12) by venepuncture after an overnight fast. Local anaesthetic patches were offered to the girls to reduce the discomfort of venepuncture. Blood samples were centrifuged (about $3000 \mathrm{~g}$ for $10 \mathrm{~min}$ ) within $2 \mathrm{~h}$ of sampling, and serum was frozen and stored at $-80^{\circ} \mathrm{C}$. Morning second 
void urine samples were collected after an overnight fast. Urine samples were frozen and stored at $-20^{\circ} \mathrm{C}$.

S-25OHD concentrations (vitamin $\mathrm{D}_{2}$ plus $\mathrm{D}_{3}$ are used here) were analysed by HPLC using a diode array detector for detection and an absorbance detector for quantification. The inter-assay $\mathrm{CV}$ was $6.3 \%$ and the intra-assay $\mathrm{CV}$ was 4.3\%. S-25OHD was analysed at the National Food Institute, Denmark. Participation in the Vitamin D External Quality Assessment Scheme (Charing Cross Hospital, London, UK) ensured that the HPLC method was in agreement with commercially available assays.

S-iPTH concentrations were analysed by an immunoradiometric method using a commercial assay (IDS, Bolton, Lancs, UK). The inter-assay CV was $4.0 \%$ and the intraassay $\mathrm{CV}$ was $2.3 \%$. Urinary $\mathrm{Ca}$ was analysed by an absorptiometry method using a KoneLab spectrophotometer (Thermo Clinical Labsystems Ltd, Espoo, Finland). The inter- and intra-assay $\mathrm{CV}$ were less than $5 \%$. S-iPTH and urinary $\mathrm{Ca}$ were analysed at the University of Helsinki, Finland.

Serum osteocalcin was analysed by an ELISA (BRI-Diagnostics, Dublin, Republic of Ireland). The inter-assay CV was $11 \%$ and the intra-assay CV was $8 \%$.

Urinary pyridinoline and deoxypyridinoline were measured by HPLC with fluorescence detection and quantified by external standardisation using a commercially available pyridinoline/ deoxypyridinoline HPLC calibrator (Metra Biosystems Ltd, Wheatley, Oxon, UK). The inter-assay $\mathrm{CV}$ was 9 and $11 \%$, respectively and the intra-assay CV was 6 and $7 \%$, respectively.

Urinary creatinine was analysed by a colorimetric procedure using a diagnostic kit (catalogue no. 124; Boehringer Mannheim $\mathrm{GmbH}$, Mannheim, Germany). The inter-assay CV was $6.7 \%$ and the intra-assay CV was $3.2 \%$.

Serum osteocalcin, urinary pyridinoline and urinary deoxypyridinoline were analysed at University College Cork (Republic of Ireland).

Serum ionised $\mathrm{Ca}$ was analysed by a $\mathrm{Ca}++/ \mathrm{pH}$ Analyser Ciba Corning 634 with ion-selective electrodes. The inter-assay $\mathrm{CV}$ was $2.4 \%$ on level $1.23 \mathrm{mmol} / \mathrm{l}$ and the intra-assay $\mathrm{CV}$ was $0.8 \%$ on level $1.16 \mathrm{mmol} / \mathrm{l}$ (external quality control: DEKS (Danish Institute for External Quality Assurance for Laboratories in Health Care)). Ionised $\mathrm{Ca}$ was analysed at the Department of Clinical Biochemistry (Hvidovre Hospital, University of Copenhagen, Denmark). Serum ionised $\mathrm{Ca}$ and urine $\mathrm{Ca}$ were measured to check for developing hypercalcaemia.

\section{Bone mineral assessment}

At the first and third visit (months 0 and 12) whole-body and lumbar (L2-L4) BMC measured in g hydroxyapatite, bone size expressed as anterior-posterior projected BA measured in $\mathrm{cm}^{2}$, and BMD measured in $\mathrm{g} / \mathrm{cm}^{2}(\mathrm{BMD}=\mathrm{BMC} / \mathrm{BA})$ were determined by DXA scan using a Hologic 1000/W scanner (Hologic, Inc., Waltham, MA, USA). The method is described elsewhere ${ }^{(1)}$.

\section{Dietary intake and background information}

At the first and third visit (months 0 and 12) the subjects answered an FFQ that ascertained the food groups contributing to $95 \%$ of the vitamin D intake and $75 \%$ of the Ca intake determined from the Danish national dietary survey, which, however, does not contain intake data from Pakistani immigrants ${ }^{(32)}$. The intake calculations were performed using the General Intake Estimation System described elsewhere ${ }^{(33,34)}$.

At the first visit (month 0) the subjects answered a detailed questionnaire that ascertained demographic characteristics, chronic diseases, use of medication and other lifestyle variables. At the second and third visit (months 6 and 12) the subjects answered a questionnaire ascertaining changes in disease or use of medication. Weight and height were recorded without shoes at all three visits. The age of the subjects at months 0 and 12 was the age on the date of blood sampling and interview. The median age difference between month 12 and 0 is 1.04 (range 0.99-1.12), 1.05 (range 0.92-1.32) and 1.05 (range $0.92-1.25$ ) years for girls, women and men, respectively (drop-outs excluded).

\section{Statistical analysis}

All statistical analyses were performed for girls, women and men separately. Analyses included standard descriptive statistics. The significance level was chosen as 0.05. SAS version 8.02 (SAS Institute, Inc., Cary, NC, USA) was used for all statistical analyses.

Non-parametric ANOVA was performed in order to compare the three treatment groups at baseline (month 0 ) in age, anthropometrics, vitamin $\mathrm{D}$ dietary intake, $\mathrm{Ca}$ dietary intake, biochemical markers and bone mass. Non-parametric ANOVA was also performed in order to compare the three treatment groups at the end of the study (month 12) in age, anthropometrics, vitamin $\mathrm{D}$ dietary intake and Ca dietary intake.

Age- and baseline-corrected multiple regression (general linear model; GLM) was performed in order to quantify the effect of tablet dose $\left(0,10\right.$ or $20 \mu \mathrm{g}$ vitamin $\left.\mathrm{D}_{3} / \mathrm{d}\right)$ on various outcomes at endpoint (12 month) as an intention-to-treat analysis. Outcomes were biochemical markers and markers for bone mass, all logarithmically transformed in order to meet the requirements of the statistical model. Likewise, the corresponding baseline measurements (month 0 ) were also logarithmically transformed, whereas age was included as a quantitative covariate without transformation. Pair-wise comparisons between the three dose groups were performed using Tukey adjustment, and effects are stated as estimated ratios between a high-dose individual compared with a low-dose individual.

In order to investigate further the dose-time interaction, we included all three time points in a repeated-measurement analysis (mixed linear model; MIXED), including subject as a random factor (compound symmetry correlation structure). Age was included as a quantitative covariate, dose and time as fixed factors, the latter described by two dummy variables indicating successive time differences.

A direct comparison of the effect over 12 months (for all variables) for dose $20 \mu \mathrm{g} / \mathrm{d}$ as compared with placebo was calculated for subjects completing the study. The effect is expressed as the ratio of change in the respective groups, so that, for example, a ratio of 2 indicates that dose $20 \mu \mathrm{g} / \mathrm{d}$ causes the variable to increase with twice the rate as compared with placebo.

\section{Results}

The baseline subject characteristics of the three treatment groups are shown in Table 1. There were no significant 
Table 1. Subject characteristics of vitamin $D_{3}$-supplemented and placebo groups at month 0 (baseline) ${ }^{\star} \dagger$ (Medians with 25th and 75th percentiles)

\begin{tabular}{|c|c|c|c|c|c|c|}
\hline \multirow[t]{2}{*}{ Group... } & \multicolumn{2}{|r|}{ Placebo } & \multicolumn{2}{|r|}{$10 \mu \mathrm{g}$} & \multicolumn{2}{|r|}{$20 \mu \mathrm{g}$} \\
\hline & Median & 25th, 75th percentiles & Median & 25th, 75th percentiles & Median & 25th, 75th percentiles \\
\hline Girls $(n)$ & \multicolumn{2}{|r|}{8} & \multicolumn{2}{|r|}{9} & \multicolumn{2}{|r|}{9} \\
\hline Age (years) & $12 \cdot 6$ & $11 \cdot 3,13 \cdot 8$ & $12 \cdot 8$ & $11 \cdot 4,13 \cdot 6$ & 11.9 & $11 \cdot 1,12 \cdot 4$ \\
\hline Weight (kg) & $50 \cdot 5$ & $43 \cdot 2,52 \cdot 9$ & 43.4 & $36 \cdot 3,54 \cdot 6$ & $49 \cdot 1$ & $40 \cdot 0,57 \cdot 9$ \\
\hline Height (cm) & $153 \cdot 7$ & $148 \cdot 5,160 \cdot 6$ & $151 \cdot 0$ & $147 \cdot 1,157 \cdot 9$ & $151 \cdot 5$ & $150 \cdot 5,158 \cdot 2$ \\
\hline BMI $\left(\mathrm{kg} / \mathrm{m}^{2}\right)$ & $21 \cdot 2$ & $17 \cdot 4,22 \cdot 4$ & $16 \cdot 5$ & $16 \cdot 2,22 \cdot 7$ & $21 \cdot 0$ & $18 \cdot 7,23 \cdot 5$ \\
\hline Dietary vitamin D intake $(\mu \mathrm{g} / \mathrm{d})$ & $2 \cdot 0$ & $1 \cdot 3,2 \cdot 4$ & 1.9 & $1 \cdot 2,2 \cdot 0$ & 1.6 & $1 \cdot 4,2 \cdot 2$ \\
\hline Dietary Ca intake $(\mathrm{mg} / \mathrm{d})$ & 510 & 309,1017 & 557 & 444,997 & 656 & 460,1281 \\
\hline Women $(n)$ & \multicolumn{2}{|r|}{29} & \multicolumn{2}{|r|}{30} & \multicolumn{2}{|r|}{ 的, } \\
\hline Age (years) & $36 \cdot 1$ & $25 \cdot 3,47 \cdot 2$ & 33.4 & $22 \cdot 9,43 \cdot 9$ & $36 \cdot 3$ & $30 \cdot 6,44 \cdot 1$ \\
\hline Weight (kg) & $68 \cdot 4$ & $57 \cdot 1,72 \cdot 3$ & $67 \cdot 1$ & $58 \cdot 1,75 \cdot 8$ & $68 \cdot 2$ & $56 \cdot 9,78 \cdot 2$ \\
\hline Height (cm) & $156 \cdot 4$ & $153 \cdot 3,161 \cdot 9$ & $159 \cdot 1$ & $155 \cdot 3,161 \cdot 1$ & $156 \cdot 7$ & $153 \cdot 0,160 \cdot 7$ \\
\hline BMI $\left(\mathrm{kg} / \mathrm{m}^{2}\right)$ & $27 \cdot 1$ & $22 \cdot 5,30 \cdot 5$ & $26 \cdot 7$ & $24 \cdot 2,30 \cdot 3$ & $27 \cdot 3$ & $22 \cdot 6,32 \cdot 0$ \\
\hline Dietary vitamin D intake $(\mu \mathrm{g} / \mathrm{d})$ & 1.5 & $1 \cdot 0,2 \cdot 5$ & $1 \cdot 7$ & $1 \cdot 3,2 \cdot 3$ & $1 \cdot 8$ & $1 \cdot 2,2 \cdot 8$ \\
\hline Dietary Ca intake $(\mathrm{mg} / \mathrm{d})$ & 495 & 350,679 & 533 & 413,638 & 459 & 299,794 \\
\hline $\operatorname{Men}(n)$ & \multicolumn{2}{|r|}{27} & \multicolumn{2}{|r|}{26} & \multicolumn{2}{|r|}{31} \\
\hline Age (years) & $40 \cdot 8$ & $31 \cdot 5,51 \cdot 1$ & $36 \cdot 6$ & $32 \cdot 5,50 \cdot 6$ & $39 \cdot 1$ & $31 \cdot 4,51 \cdot 5$ \\
\hline Weight (kg) & $77 \cdot 2$ & $71 \cdot 2,89 \cdot 0$ & $81 \cdot 7$ & $74 \cdot 0,92 \cdot 6$ & $77 \cdot 4$ & $67 \cdot 9,83 \cdot 0$ \\
\hline Height $(\mathrm{cm})$ & $170 \cdot 7$ & $167 \cdot 7,175 \cdot 2$ & $174 \cdot 5$ & $169 \cdot 8,177 \cdot 9$ & $168 \cdot 3$ & $165 \cdot 1,176 \cdot 7$ \\
\hline BMI $\left(\mathrm{kg} / \mathrm{m}^{2}\right)$ & $27 \cdot 0$ & $25 \cdot 3,30 \cdot 6$ & $27 \cdot 6$ & $25 \cdot 2,28 \cdot 2$ & $25 \cdot 8$ & $23 \cdot 7,29 \cdot 9$ \\
\hline Dietary vitamin D intake $(\mu \mathrm{g} / \mathrm{d})$ & $2 \cdot 1$ & $1 \cdot 5,3 \cdot 5$ & $1 \cdot 8$ & $1 \cdot 6,3 \cdot 3$ & $2 \cdot 4$ & $1 \cdot 7,4 \cdot 9$ \\
\hline Dietary Ca intake $(\mathrm{mg} / \mathrm{d})$ & 548 & 428,780 & 541 & 472,772 & 581 & 481,765 \\
\hline
\end{tabular}

*No significant difference between treatment groups at baseline $(P>0.05$; non-parametric ANOVA).

†Baseline characteristics of drop-outs were not significantly different from those completing the study $(P>0.05$; non-parametric ANOVA).

differences $(P>0.05$; non-parametric ANOVA) between the three treatment groups in subject characteristics either at baseline (month 0) (Table 1) or at the end of the study (month 12) (data not shown). There was also no significant difference between the three treatment groups at baseline in S-25OHD, S-iPTH, serum osteocalcin, urinary pyridinoline and urinary deoxypyridinoline for girls, women and men (Tables 2 and 3). Serum ionised $\mathrm{Ca}$ and urinary $\mathrm{Ca}$ were measured at all three visits. No subjects developed hypercalcaemia (serum ionised Ca was below $1.5 \mathrm{mmol} / \mathrm{l}$ for all subjects at all visits). There was no significant difference $(P>0.05$; non-parametric ANOVA) between the three treatment groups in serum and urinary $\mathrm{Ca}$ either at baseline (month 0) or at the end of the study (month 12) (data not shown).

\section{Serum 25-hydroxyvitamin D}

There was a significant difference (Table 2; GLM) between the three treatment groups at end of the study (month 12) in S-25OHD for girls, women and men. Vitamin D supplementation elevated median S-25OHD concentrations in all groups; for women concentration increased by 31$32 \mathrm{nmol} / \mathrm{l}$ with both 10 and $20 \mu \mathrm{g} / \mathrm{d}$, and for the men $\mathrm{S}-25 \mathrm{OHD}$ increased $16.5 \mathrm{nmol} / \mathrm{l}$ with $10 \mu \mathrm{g} / \mathrm{d}$ and $35.8 \mathrm{nmol} /$ 1 with $20 \mu \mathrm{g} / \mathrm{d}$ (the baseline and final values are shown in Table 2). Vitamin D status of the women increased about four times by intake of both 10 and $20 \mu \mathrm{g} / \mathrm{d}$; for men vitamin D status increased about two times by intake of $10 \mu \mathrm{g} / \mathrm{d}$ and about three times by $20 \mu \mathrm{g} / \mathrm{d}$ (Table 2; GLM). S-25OHD concentration increased significantly between months 0 and 6 , and did not increase further from months 6 to 12 (Table 2; MIXED). However, there were individuals with increased S-25OHD during months 6 to 12, as seen in Fig. 1, which shows the S-25OHD raw data and illustrates the entire course of the intervention.

Figure 2 shows the relationship between the outcome and baseline S-25OHD concentrations (logarithmically transformed) for women and men (not shown for girls due to the low number of subjects). As seen in Fig. 2, the outcome concentrations depend on baseline values both for intake of 10 and $20 \mu \mathrm{g} / \mathrm{d}$ for women, and the slope is similar for both treatment groups ( $\alpha=0.3$ and 0.2 for doses 10 and $20 \mu \mathrm{g} / \mathrm{d}$, respectively). For men the endpoint concentrations depend on baseline values only for intake of $10 \mu \mathrm{g} / \mathrm{d}(\alpha=0 \cdot 3)$, whereas for the $20 \mu \mathrm{g} / \mathrm{d}$ treatment group the slope was close to zero $(\alpha=-0.004)$ and thus independent of the baseline value. This illustrates an interaction between dose and baseline value, which is confirmed by including this interaction term in the GLM analysis; the interaction is significant for men $(P=0.0045)$, but not for women.

\section{Serum intact parathyroid hormone}

Vitamin D supplementation decreased S-iPTH significantly between months 0 and 6 for girls, women and men, but not between months 6 and 12 (Table 2; MIXED). There was a significant difference between the three treatment groups at the end of the study (month 12) for women, but not for girls and men (Table 2; GLM). There was no significant difference in S-iPTH between dose 10 and $20 \mu \mathrm{g} / \mathrm{d}$ for girls, women and men (data not shown).

\section{Bone turnover (serum osteocalcin, urinary pyridinoline and} urinary deoxypyridinoline)

There was no significant difference (GLM) between the three treatment groups at the end of the study (month 12) and there 
Table 2. Serum 25-hydroxy vitamin $\mathrm{D}(\mathrm{S}-25 \mathrm{OHD})$ and serum intact parathyroid hormone (S-iPTH) in the three treatment groups at month 0,6 and 12 , and $P$ values from the two statistical tests performed (general linear model (GLM) and mixed linear model (MIXED))

(Medians with 25th and 75th percentiles)

\begin{tabular}{|c|c|c|c|c|c|c|c|c|c|c|c|c|}
\hline & \multicolumn{4}{|c|}{ Girls } & \multicolumn{4}{|c|}{ Women } & \multicolumn{4}{|c|}{ Men } \\
\hline & \multicolumn{2}{|c|}{$\mathrm{S}-25 \mathrm{OHD}(\mathrm{nmol} / \mathrm{l})$} & \multicolumn{2}{|c|}{ S-iPTH (pmol/l) } & \multicolumn{2}{|c|}{$\mathrm{S}-25 \mathrm{OHD}(\mathrm{nmol} / \mathrm{l})$} & \multicolumn{2}{|c|}{ S-iPTH (pmol/l) } & \multicolumn{2}{|c|}{$\mathrm{S}-25 \mathrm{OHD}(\mathrm{nmol} / \mathrm{l})$} & \multicolumn{2}{|c|}{ S-iPTH (pmol/l) } \\
\hline & Median & $\begin{array}{l}\text { 25th, } 75 \text { th } \\
\text { percentiles }\end{array}$ & Median & $\begin{array}{l}\text { 25th, } 75 \text { th } \\
\text { percentiles }\end{array}$ & Median & $\begin{array}{l}\text { 25th, } 75 \text { th } \\
\text { percentiles }\end{array}$ & Median & $\begin{array}{l}\text { 25th, } 75 \text { th } \\
\text { percentiles }\end{array}$ & Median & $\begin{array}{l}\text { 25th, } 75 \text { th } \\
\text { percentiles }\end{array}$ & Median & $\begin{array}{l}\text { 25th, } 75 \text { th } \\
\text { percentiles }\end{array}$ \\
\hline \multicolumn{13}{|l|}{ Placebo } \\
\hline Subjects month $0(n)$ & & & 8 & & & & 29 & & & 2 & & \\
\hline Subjects month $6(n)$ & & & 7 & & & & 20 & & & & & \\
\hline Subjects month $12(n)$ & & & 7 & & & & 19 & & & & & \\
\hline Month $0^{*}$ & $7 \cdot 30$ & $5 \cdot 30,23 \cdot 6$ & 3.97 & $3 \cdot 58,5 \cdot 74$ & 11.7 & $7 \cdot 5,19 \cdot 4$ & 4.02 & $2 \cdot 99,5 \cdot 12$ & $20 \cdot 0$ & $15 \cdot 0,25 \cdot 2$ & 3.50 & $2.71,4.04$ \\
\hline Month 6 & 7.97 & $5.33,18.5$ & 4.92 & $2 \cdot 69,8 \cdot 29$ & 5.72 & $4.96,10.5$ & $4.47 \dagger$ & $3.78,5.55$ & $12 \cdot 1$ & $7 \cdot 90,18 \cdot 8$ & 3.35 & $2.95,4.08$ \\
\hline Month 12 & 5.75 & $4 \cdot 88,16 \cdot 0$ & $4.03 \ddagger$ & $3 \cdot 22,5 \cdot 34$ & $10 \cdot 1$ & $8 \cdot 38,16 \cdot 1$ & 3.92 & $2.82,4.80$ & $19 \cdot 1$ & $13 \cdot 1,22 \cdot 6$ & $3 \cdot 30$ & $2 \cdot 65,3.71$ \\
\hline \multicolumn{13}{|l|}{$10 \mu \mathrm{g} / \mathrm{d}$} \\
\hline Subjects month $0(n)$ & & & 9 & & & & 30 & & & & & \\
\hline Subjects month $6(n)$ & & & 7 & & & & 22 & & & & & \\
\hline Subjects month $12(n)$ & & & 7 & & & & 21 & & & & & \\
\hline Month $0^{*}$ & 16.9 & $12 \cdot 1,21 \cdot 1$ & 3.53 & $2.74,4.94$ & 9.95 & $6 \cdot 90,14 \cdot 3$ & 3.46 & $2 \cdot 90,4 \cdot 20$ & $22 \cdot 9$ & $12 \cdot 6,28 \cdot 2$ & 3.14 & $2 \cdot 77,4 \cdot 13$ \\
\hline Month 6 & $45 \cdot 7$ & $30 \cdot 4,54 \cdot 3$ & $2 \cdot 87$ & $1.73,3.81$ & 43.4 & $38 \cdot 7,49 \cdot 4$ & 2.96 & $2 \cdot 63,4 \cdot 11$ & 37.8 & $27 \cdot 1,45 \cdot 5$ & $2 \cdot 70 \dagger$ & $2 \cdot 38,3 \cdot 30$ \\
\hline Month 12 & $47 \cdot 0$ & $28 \cdot 7,61.5$ & $2 \cdot 75$ & $1.55,3.38$ & 40.9 & $37 \cdot 4,47 \cdot 7$ & $2 \cdot 62$ & $2 \cdot 14,2 \cdot 94$ & 39.4 & $31 \cdot 0,48 \cdot 2$ & $2 \cdot 76 \S$ & $2 \cdot 13,3.80$ \\
\hline \multicolumn{13}{|l|}{$20 \mu \mathrm{g} / \mathrm{d}$} \\
\hline Subjects month $0(n)$ & & & 9 & & & & 30 & & & & & \\
\hline Subjects month $6(n)$ & & & 8 & & & & 23 & & & & & \\
\hline Subjects month $12(n)$ & & & 7 & & & & 22 & & & & & \\
\hline Month $0^{*}$ & 8.80 & $5 \cdot 20,17 \cdot 1$ & $4 \cdot 29$ & $2 \cdot 90,5 \cdot 61$ & $14 \cdot 0$ & $8 \cdot 30,17 \cdot 5$ & 3.69 & $2 \cdot 78,4 \cdot 61$ & 18.9 & $13 \cdot 6,29 \cdot 2$ & 3.44 & $2 \cdot 72,4 \cdot 27$ \\
\hline Month 6 & $51 \cdot 1$ & $31 \cdot 8,57 \cdot 9$ & $2 \cdot 56$ & $1.66,3.67$ & $46 \cdot 4$ & $30 \cdot 1,53 \cdot 4$ & $3 \cdot 11 \|$ & $2 \cdot 80,2 \cdot 88$ & 53.6 & $47 \cdot 0,62 \cdot 8$ & $2 \cdot 63$ & $2 \cdot 22,3.63$ \\
\hline Month 12 & $29 \cdot 3$ & $28 \cdot 5,64.0$ & 2.90 & $1.15,3.56$ & $46 \cdot 2$ & $38 \cdot 6,53 \cdot 2$ & 3.06 & $2 \cdot 33,3 \cdot 62$ & 54.7 & $45 \cdot 2,65 \cdot 1$ & 3.04 & $2 \cdot 54,4 \cdot 35$ \\
\hline Ratio of change $(\mathrm{Cl})$ ? & 3.61 & $1.54,8.45$ & 0.62 & $0.36,1.07$ & 4.94 & $3.93,6.22$ & 0.89 & $0.69,1 \cdot 15$ & $3 \cdot 27$ & $2.33,4.58$ & 0.98 & $0.77,1.24$ \\
\hline \multicolumn{13}{|l|}{$P$ value $($ ratio** $)$} \\
\hline \multicolumn{13}{|l|}{ GLM } \\
\hline Dose $0-10$ & $0.03(3.48)$ & & NS & & $<0.0001(4.04)$ & & $0.001(0.68)$ & & $<0.0001(2.10)$ & & NS & \\
\hline Dose $0-20$ & NS & & NS & & $<0.0001(4.19)$ & & NS & & $<0.0001(3.09)$ & & NS & \\
\hline Dose $10-20$ & NS & & NS & & NS & & NS & & 0.006 & & NS & \\
\hline \multicolumn{13}{|l|}{ MIXED } \\
\hline Month 0-6 & 0.004 & & 0.02 & & $<0.0001$ & & 0.0007 & & $<0.0001$ & & 0.03 & \\
\hline Month 6-12 & NS & & NS & & NS & & NS & & NS & & NS & \\
\hline
\end{tabular}

\section{NS, non-significant $(P>0.05)$}

${ }^{*}$ No significant difference between treatment groups at baseline (month 0$)(P>0.05$; non-parametric ANOVA).

†n 19 .

$\S n 18$.

I Ratio of change (Cl) over 12 months for dose $20 \mu \mathrm{g} / \mathrm{d}$ as compared with placebo for subjects completing the study.

${ }^{\star *}$ Effects are stated as estimated ratios between a high-dose individual compared with a low-dose individual. 
Table 3. Serum osteocalcin (S-Osteo), urine pyridinoline (U-Pyr) and urine deoxypyrodinoline (U-dPyr) in the three treatment groups at months 0,6 and 12

(Medians with 25th and 75th percentiles)

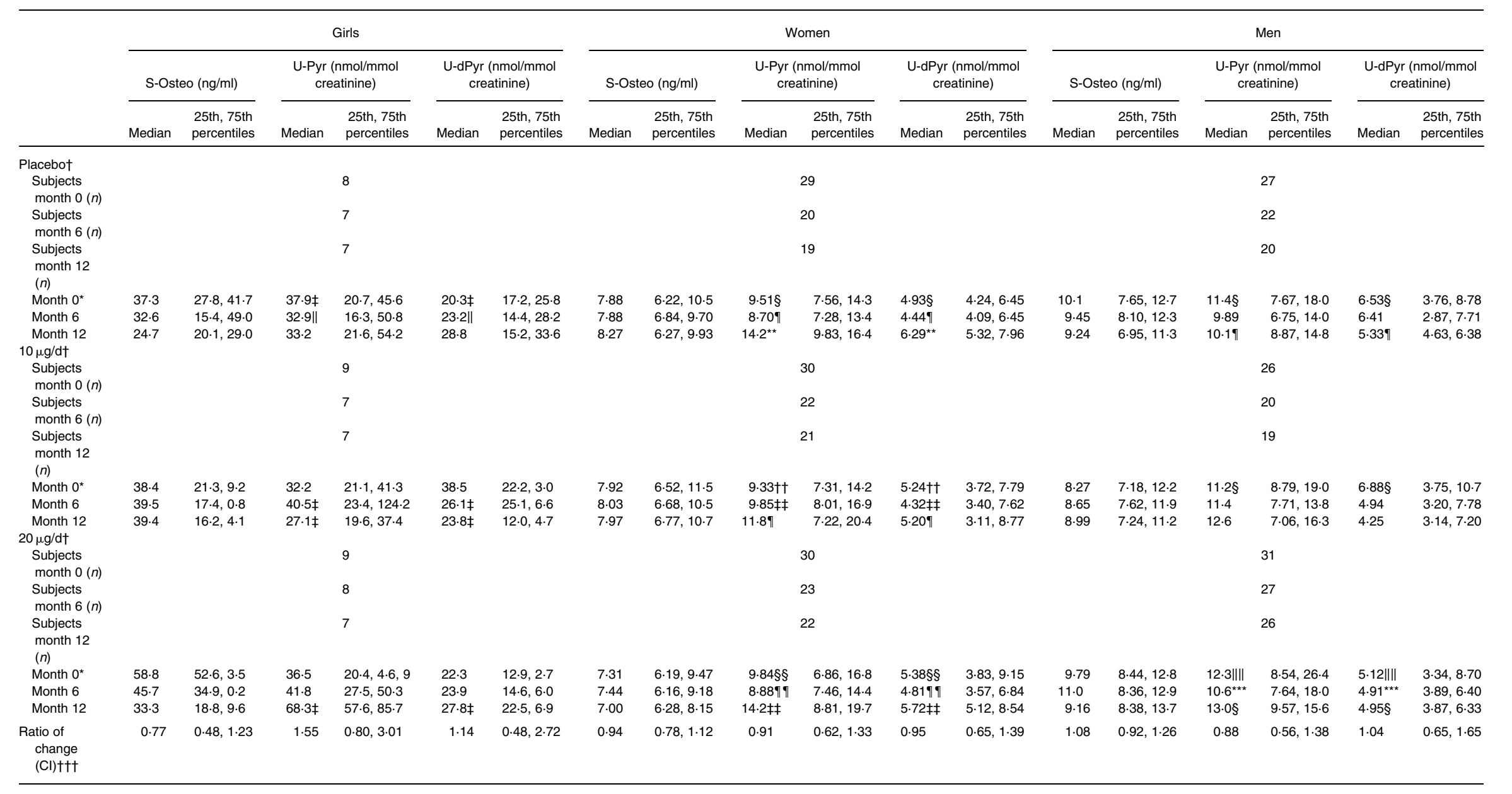

*No significant difference between treatment groups at baseline (month 0) $(P>0.05$; non-parametric ANOVA).

† No significant difference between treatment groups $(P>0.05$; general linear model and mixed linear model).

$\ddagger n 6$.

$\$ n 25$.

In $n$ 19.

** $n 18$.

†† $n 29$.

拉 $n 21$.

$\S \S n 27$.

IIII $n 30$.

$\prod \pi n 23$.

t†t Ratio of change $(\mathrm{Cl})$ over 12 months for dose $20 \mu \mathrm{g} / \mathrm{d}$ as compared with placebo for subjects completing the study. 

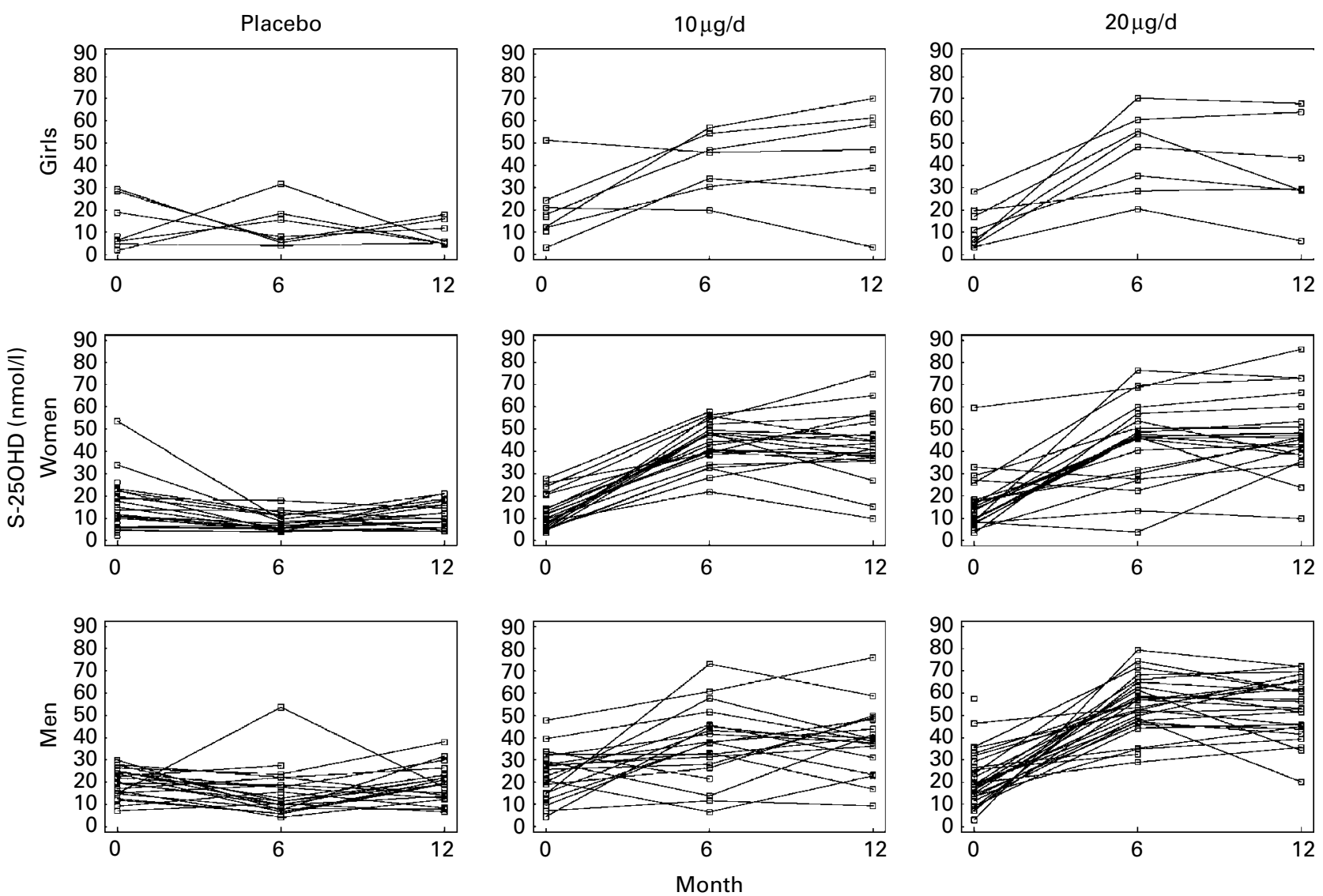

Fig. 1. The effect of vitamin D supplementation on serum 25-hydroxyvitamin D (S-25OHD) concentrations (nmol/l) for each subject (girls, women and men separately) in each treatment group (placebo, $10 \mu \mathrm{g}$ vitamin $\mathrm{D}_{3} / \mathrm{d}$ and $20 \mu \mathrm{g}$ vitamin $\mathrm{D}_{3} / \mathrm{d}$ ) at visit 1 (month 0 , baseline), visit 2 (month 6 ) and visit 3 (month 12 , outcome).

was no significant dose-time interaction for any of the bone turnover markers for girls, women and men (MIXED) (Table 3). Based on the confidence limits (Table 3), we cannot rule out the possibility of a clinically relevant effect; an effect might have been found if we had studied more subjects.

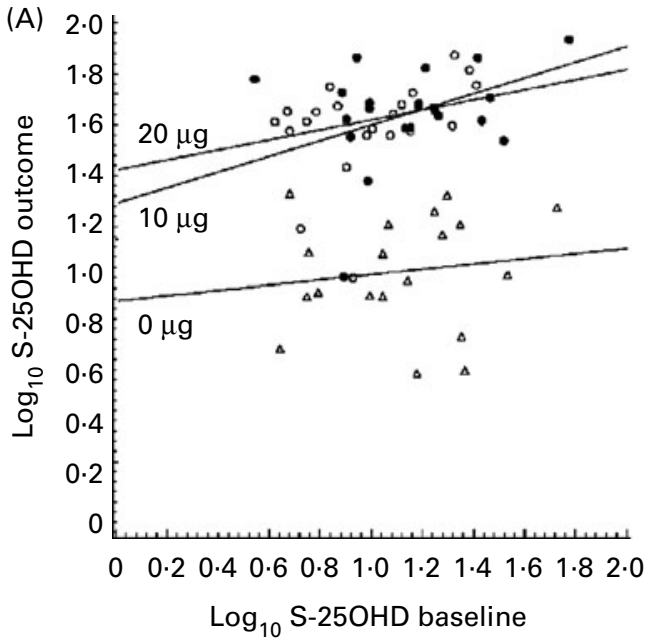

Bone mass (whole-body and lumbar spine bone mineral content, bone area and bone mineral density)

There was no significant difference (non-parametric ANOVA) between the three treatment groups at baseline in whole-body and lumbar spine $\mathrm{BMC}, \mathrm{BA}$ and $\mathrm{BMD}$ for women and girls

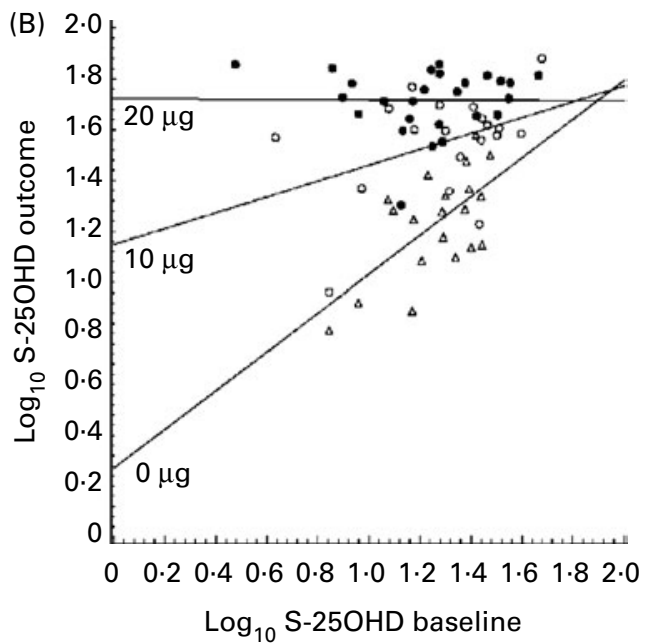

Fig. 2. The relationship between endpoint and baseline serum 25-hydroxyvitamin $D(S-25 O H D)$ (logarithmically transformed) for each subject (women (A) and men $(B)$ separately) in each treatment group (placebo $(\triangle), 10 \mu \mathrm{g}$ vitamin $D_{3} / \mathrm{d}(\bigcirc)$ and $20 \mu \mathrm{g}$ vitamin $D_{3} / \mathrm{d}(\bullet)$ ). 
Table 4. Whole-body and lumbar spine bone mineral content (BMC), bone area (BA) and bone mineral density (BMD) in the three treatment groups at months 0 and 12

(Medians with 25th and 75th percentiles)

\begin{tabular}{|c|c|c|c|c|c|c|c|c|c|c|c|c|c|c|c|c|c|c|}
\hline & \multicolumn{6}{|c|}{ Girls } & \multicolumn{6}{|c|}{ Women } & \multicolumn{6}{|c|}{ Men } \\
\hline & \multicolumn{2}{|c|}{ BMC (g) } & \multicolumn{2}{|c|}{$\mathrm{BA}\left(\mathrm{cm}^{2}\right)$} & \multicolumn{2}{|c|}{$\operatorname{BMD}\left(\mathrm{g} / \mathrm{cm}^{2}\right)$} & \multicolumn{2}{|c|}{ BMC (g) } & \multicolumn{2}{|c|}{$\mathrm{BA}\left(\mathrm{cm}^{2}\right)$} & \multicolumn{2}{|c|}{$\operatorname{BMD}\left(\mathrm{g} / \mathrm{cm}^{2}\right)$} & \multicolumn{2}{|c|}{ BMC (g) } & \multicolumn{2}{|c|}{$\mathrm{BA}\left(\mathrm{cm}^{2}\right)$} & \multicolumn{2}{|c|}{$\operatorname{BMD}\left(\mathrm{g} / \mathrm{cm}^{2}\right)$} \\
\hline & Median & $\begin{array}{l}25 \text { th, } 75 \text { th } \\
\text { percentiles }\end{array}$ & Median & $\begin{array}{l}25 \text { th, } 75 \text { th } \\
\text { percentiles }\end{array}$ & Median & $\begin{array}{l}\text { 25th, } 75 \text { th } \\
\text { percentiles }\end{array}$ & Median & $\begin{array}{l}25 \text { th, } 75 \text { th } \\
\text { percentiles }\end{array}$ & Median & $\begin{array}{l}25 \text { th, } 75 \text { th } \\
\text { percentiles }\end{array}$ & Median & $\begin{array}{l}\text { 25th, } 75 \text { th } \\
\text { percentiles }\end{array}$ & Median & $\begin{array}{l}25 \text { th, } 75 \text { th } \\
\text { percentiles }\end{array}$ & Median & $\begin{array}{l}\text { 25th, } 75 \text { th } \\
\text { percentiles }\end{array}$ & Median & $\begin{array}{l}25 \text { th, } 75 \text { th } \\
\text { percentiles }\end{array}$ \\
\hline \multicolumn{19}{|l|}{ Placeboł } \\
\hline \multicolumn{19}{|l|}{ Whole body } \\
\hline Month $0(n)$ & & & & 8 & & & & & & 28 & & & & & & 26 & & \\
\hline Month $12(n)$ & & & & 7 & & & \multicolumn{6}{|c|}{19} & \multicolumn{6}{|c|}{18} \\
\hline Month $0^{*}$ & 1666 & 1399, 1767 & 1760 & 1561,1822 & 0.95 & $0.88,0.98$ & 2241 & 1983,2469 & 2055 & 1833,2126 & 1.11 & $1.05,1.15$ & 2637 & 2390,2912 & 2281 & 2111,2358 & 1.16 & $1.08,1.23$ \\
\hline Month 12 & 1923 & 1730,2145 & 1906 & 1770,2123 & 1.01 & $0.97,1.03$ & 2302 & 2098,2541 & 2043 & 1932, 2176 & 1.13 & $1.09,1.20$ & 2778 & 2420,2873 & 2299 & 2160,2390 & 1.19 & $1 \cdot 14,1 \cdot 24$ \\
\hline \multicolumn{19}{|l|}{ Lumbar spine } \\
\hline Month $0(n)$ & & & & 8 & & & \multirow{2}{*}{\multicolumn{6}{|c|}{$\begin{array}{l}29 \\
18\end{array}$}} & \multirow{2}{*}{\multicolumn{6}{|c|}{$\begin{array}{l}27 \\
19\end{array}$}} \\
\hline Month $12(n)$ & & & & 7 & & & & & & & & & & & & & & \\
\hline Month $0^{*}$ & 33.9 & $26 \cdot 1,42 \cdot 4$ & 43.2 & $38.4,47.0$ & 0.78 & $0.66,0.92$ & 49.0 & $45 \cdot 0,59 \cdot 9$ & 50.1 & $48 \cdot 1,55 \cdot 3$ & 0.99 & $0.91,1.12$ & 63.0 & $53 \cdot 3,69 \cdot 8$ & 61.3 & $57 \cdot 6,64 \cdot 1$ & 1.03 & $0.96,1 \cdot 14$ \\
\hline Month 12 & 41.9 & $38 \cdot 9,48 \cdot 2$ & 46.5 & $44.7,50 \cdot 3$ & 0.91 & $0.84,0.95$ & 50.1 & $45 \cdot 6,60 \cdot 7$ & 50.6 & $47 \cdot 4,53.9$ & 1.00 & $0.89,1.16$ & 66.9 & $59 \cdot 1,74 \cdot 3$ & 60.9 & $58 \cdot 3,64 \cdot 4$ & 1.06 & $0.90,1 \cdot 14$ \\
\hline \multirow{2}{*}{\multicolumn{19}{|c|}{$\begin{array}{l}10 \mu \mathrm{g} / \mathrm{d} \neq \\
\text { Whole body }\end{array}$}} \\
\hline \multirow{2}{*}{\multicolumn{19}{|c|}{$\begin{array}{l}\text { Whole body } \\
\text { Month } 0(n)\end{array}$}} \\
\hline & & & & & & & & & & & & & & & & & & \\
\hline Month $12(n)$ & & & & 7 & & & & & & 21 & & & & & & 18 & & \\
\hline Month $0^{*}$ & 1308 & 1104,1726 & 1497 & 1339, 1725 & 0.87 & $0.82,0.99$ & 2222 & 2043,2512 & 2032 & 1858,2197 & $1 \cdot 10$ & $1.04,1.17$ & 2684 & 2406,2779 & 2325 & 2168,2398 & 1.14 & $1.09,1.20$ \\
\hline Month 12 & 1595 & 1302,1953 & 1669 & 1534,1872 & 0.96 & $0.85,1.04$ & 2172 & 1947,2536 & 2007 & 1841,2148 & $1 \cdot 11$ & $1.04,1 \cdot 18$ & 2703 & 2474,2869 & 2334 & 2168,2438 & 1.16 & $1 \cdot 11,1 \cdot 18$ \\
\hline Lumbar spine & & & & & & & & & & & & & & & & & & \\
\hline Month $0(n)$ & & & & 9 & & & & & & 30 & & & & & & 25 & & \\
\hline Month $12(n)$ & & & & 7 & & & & & & 21 & & & & & & 19 & & \\
\hline Month $0^{*}$ & 28.3 & $24 \cdot 7,35 \cdot 8$ & 41.2 & $35 \cdot 6,45 \cdot 9$ & 0.72 & $0.65,0.83$ & 54.7 & $49 \cdot 9,62 \cdot 2$ & 51.9 & $48 \cdot 0,56 \cdot 3$ & 1.06 & $0.99,1.06$ & 66.5 & $58 \cdot 5,71 \cdot 7$ & 64.1 & $59 \cdot 3,67 \cdot 5$ & 1.03 & $0.94,1.07$ \\
\hline Month 12 & 35.6 & $30 \cdot 9,47 \cdot 4$ & $42 \cdot 7$ & $38 \cdot 8,48 \cdot 9$ & 0.82 & $0.78,0.96$ & 55.5 & $49 \cdot 4,59 \cdot 8$ & 51.6 & $48 \cdot 3,55 \cdot 0$ & 1.06 & $1 \cdot 01,1 \cdot 11$ & 68.2 & $60 \cdot 4,72.9$ & 64.6 & $61 \cdot 8,68 \cdot 4$ & 1.05 & $0.97,1.11$ \\
\hline $20 \mu \mathrm{g} / \mathrm{d} \neq$ & & & & & & & & & & & & & & & & & & \\
\hline Whole body & & & & & & & & & & & & & & & & & & \\
\hline Month $0(n)$ & & & & 9 & & & & & & 30 & & & & & & 28 & & \\
\hline Month $12(n)$ & & & & 7 & & & & & & 22 & & & & & & 23 & & \\
\hline Month $0^{*} \dagger$ & 1473 & 1209, 1887 & 1633 & 1441,1973 & 0.88 & $0.84,0.93$ & 2208 & 1997,2370 & 2001 & 1891,2109 & 1.09 & $1.06,1 \cdot 14$ & 2418 & 2144,2635 & 2101 & 1986, 2278 & 1.11 & $1.08,1 \cdot 20$ \\
\hline Month 12 & 1625 & 1380,2140 & 1784 & 1569, 2026 & 0.91 & $0.88,1.05$ & 2221 & 2012, 2291 & 2032 & 1888,2093 & 1.08 & $1.05,1 \cdot 11$ & 2437 & 2104,2644 & 2116 & 1929, 2285 & $1 \cdot 10$ & $1 \cdot 08,1 \cdot 21$ \\
\hline Lumbar spine & & & & & & & & & & & & & & & & & & \\
\hline Month $0(n)$ & & & & 9 & & & & & & 30 & & & & & & 31 & & \\
\hline Month $12(n)$ & & & & 7 & & & & & & 21 & & & & & & 26 & & \\
\hline Month $0^{*} \dagger$ & 30.0 & $25 \cdot 4,32 \cdot 5$ & 39.9 & $37 \cdot 9,42 \cdot 2$ & 0.73 & $0.67,0.75$ & 50.6 & $46 \cdot 1,55 \cdot 8$ & 50.5 & $48 \cdot 1,55 \cdot 1$ & 0.98 & $0.93,1.05$ & 55.6 & $49 \cdot 0,64 \cdot 8$ & 58.3 & $54 \cdot 8,62 \cdot 9$ & 0.92 & $0.89,1.08$ \\
\hline Month 12 & 39.5 & $27 \cdot 6,41 \cdot 9$ & $42 \cdot 7$ & $38 \cdot 7,46 \cdot 0$ & 0.88 & $0.73,0.95$ & 50.4 & $46 \cdot 7,55 \cdot 4$ & $50 \cdot 0$ & $48 \cdot 5,53 \cdot 1$ & 0.99 & $0.93,1.08$ & $56 \cdot 3$ & $50 \cdot 9,67.8$ & $57 \cdot 2$ & $55 \cdot 2,62 \cdot 3$ & 1.00 & $0.88,1.12$ \\
\hline $\begin{array}{l}\text { Ratio of change } \\
\text { (Cl) whole } \\
\text { body§ }\end{array}$ & 1.04 & $0.96,1 \cdot 13$ & 1.03 & $0.97,1.09$ & 1.02 & $0.98,1.05$ & 1.01 & $0.996,1.02$ & 1.02 & $1.005,1.03$ & 0.99 & $0.98,0.999$ & 1.01 & $1.005,1.02$ & 1.01 & $0.998,1.02$ & 1.01 & $0.999,1.01$ \\
\hline $\begin{array}{l}\text { Ratio of change } \\
\text { (CI) lumbar } \\
\text { spine§ }\end{array}$ & 1.08 & $0.95,1.23$ & 1.02 & $0.96,1.07$ & 1.07 & $0.99,1 \cdot 16$ & 1.01 & $0.98,1.03$ & 1.00 & $0.98,1.01$ & 1.01 & $0.996,1.02$ & 1.02 & $0.999,1.05$ & 1.01 & $0.998,1.02$ & 1.02 & $0.997,1.04$ \\
\hline
\end{tabular}

${ }^{*}$ No significant difference between treatment groups at baseline (month 0) ( $P>0.05$; non-parametric ANOVA).

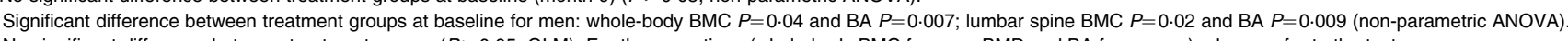

for men, BMD and BA for women), please refer to the text.

$\S$ Ratio of change $(\mathrm{Cl})$ over 12 months for dose $20 \mu \mathrm{g} / \mathrm{d}$ as compared with placebo for subjects completing the study. 
(Table 4). There were, however, significant differences between the three treatment groups at baseline for men in whole-body and lumbar spine BMC and BA (Table 4).

There was no significant difference (GLM) between the three treatment groups at the end of the study (month 12) in BMC, BA and BMD (whole body and lumbar spine) for girls. For men there was a significant increase in whole-body BMC $(P=0 \cdot 049$; ratio $=1.01)$ by supplementation with $20 \mu \mathrm{g} / \mathrm{d}$. For women there was a significant increase in whole-body BA $(P=0.02$; ratio $=1.02)$ and significant decrease in whole-body BMD $(P=0.02$; ratio $=0.99)$ by supplementation with $20 \mu \mathrm{g} / \mathrm{d}$. The different directions of the estimated ratios weaken these findings for women. There was no significant difference in any of the lumbar spine bone parameters for women and men. The confidence limits (Table 4) did not indicate clinical relevant effects on bone mass

\section{Discussion}

The present study showed that supplementation with 10 and $20 \mu \mathrm{g}$ vitamin $\mathrm{D}_{3}$ per $\mathrm{d}$ increased $\mathrm{S}-25 \mathrm{OHD}$ concentrations similarly in vitamin D-deficient Pakistani women (4-fold), and that $10 \mu \mathrm{g}$ increased S-25OHD concentrations 2-fold and $20 \mu \mathrm{g}$ 3-fold in Pakistani men. S-25OHD concentrations increased at 6 months and were stable thereafter. Baseline S-25OHD concentrations tended to be lower in girls and women than in men; females achieved about $46 \mathrm{nmol} / \mathrm{l}$ and men $55 \mathrm{nmol} / 1$ after supplementation. S-iPTH concentrations decreased at 6 months, and there was no significant difference in S-iPTH between the 10 and $20 \mu \mathrm{g} / \mathrm{d}$ treatment groups.

The other main finding of the present study was the lack of significant effect of the vitamin D intervention on bone turnover markers and on markers of bone mass (BMC, BMD, BA).

For girls, the lack of significant effects could be due to lack of statistical power, since fewer than the scheduled sixty subjects were recruited. For women, the different directions of the estimated ratios (0.99 and 1.02) weaken the significant differences found (whole-body BMD and BA), and for men, the only significant $P$ value (whole-body BMC; 0.049) was close to $0 \cdot 05$, and it cannot be concluded that vitamin D supplementations had an effect on bone mass. One could discuss whether the S-25OHD values are high enough to affect the bone parameters; the S-25OHD concentrations did not reach $70-80 \mathrm{nmol} / 1$, which is often considered the optimal concentration for bone health ${ }^{(35)}$, at least among elderly Caucasians. However, in the present study there was no significant difference in S-iPTH between the 10 and $20 \mu \mathrm{g} / \mathrm{d}$ treatment groups. Further studies in different ethnic population groups are needed to clarify whether doses above $20 \mu \mathrm{g} / \mathrm{d}$ and study durations longer than 1 year would increase S-25OHD and decrease S-iPTH further and thereby improve bone health.

The non-random recruitment of the sample is a limitation of the present study. The drop-out rate was high; however, we expected this problem and mitigated it by recruiting more subjects to start with (except for the girls, since parents were not very willing to let their daughters participate). The compliance was calculated by tablet counting, but we could obviously not control the actual tablet intake. It was not within the scope of this project to measure muscle strength; however, it could have been interesting to do so. We did ask questions about muscle pain (duration and degree). However, the questions were compounded by language difficulties; consequently the questions were not included in the analyses. In the discussion of optimal vitamin D status one must keep in mind the difficulties in comparing S-25OHD concentrations in different studies due to large inter-laboratory variations ${ }^{(36-38)}$

The clinical trials evaluating the effect of vitamin D supplementation on bone mass and/or fracture risk are mainly performed among Caucasians elderly women, some even frail or institutionalised $^{(7,11)}$, and the trials have produced conflicting results $^{(7-12)}$. The specific benefit to be gained from increasing vitamin D intake remains to be defined for other ethnic groups. It has been suggested that vitamin D supplementation is likely to have favourable effects on the skeleton among black subjects ${ }^{(39)}$; however, a 3-year randomised controlled trial of vitamin D supplementation $(20-50 \mu \mathrm{g} / \mathrm{d})$ in Ca-replete postmenopausal African-American women did not find an effect on bone loss or bone turnover markers ${ }^{(30)}$. Whether the lack of effect on bone turnover and bone density is due to ethnic differences or other reasons, we do not know. Studies from Norway found similar BMD and bone turnover markers among Pakistanis and Norwegians in spite of different S-25OHD ${ }^{(40,41)}$.

Even though we did not find a beneficial effect of vitamin D supplementation on bone parameters, the improved vitamin D status among immigrants might affect muscle strength and the risk of other diseases beneficially. Hypovitaminosis D myopathy is a prominent symptom of vitamin D deficiency, and severely impaired muscle function may be present even before biochemical signs of bone disease develop ${ }^{(22)}$. Besides, vitamin $\mathrm{D}$ deficiency may increase the risk of several other diseases, for example, autoimmune diseases, some types of cancers, and diabetes ${ }^{(42)}$.

Convincing immigrants to consume supplemental vitamin D every day for a longer period of time would certainly represent a major challenge. Food fortification could be a more realistic solution. The relatively low dosages used in the present study were chosen with a view to the possibility of fortification. Presently in Denmark margarine can voluntarily be fortified with $7 \cdot 5-10 \mu \mathrm{g}$ vitamin D per $100 \mathrm{~g}$. Fortification of chapatti flour, which could be a way to reach Pakistani immigrants, was tested in the 1970s in the UK, but it was not recommended, since the age consumption pattern was not favourable to the aims of fortification and not all Asians eat chapatti ${ }^{24,43)}$. Muslim immigrants in Denmark are now recommended through information leaflets to take $10 \mu \mathrm{g}$ vitamin D supplements/d.

The present study on one hand clearly demonstrates that the vitamin D status of severely vitamin D-deficient Pakistani immigrants in Denmark increases two to four times with relatively small dosages of supplemental vitamin $\mathrm{D}$, and that S-iPTH decreases at the same time. On the other hand, this improvement in vitamin D and PTH status did not benefit bone mass and bone turnover parameters. The optimal vitamin D nutrition for skeletal health in different ethnic groups should be further investigated.

\section{Acknowledgements}

We thank Karin Hess Ygil, Dorte Strange and Nighat Kwajada for interviewing the participants; Nighat Kwajada for the blood sampling and the interpretation into Urdu when necessary; Dorte Strange for the DXA scannings; Birgitte 
Hermansen for assisting the DXA scannings and assisting designing the FFQ; Karin Hess Ygil, Tue Christensen and Anders Møller for the dietary intake calculations. The study is part of the OPTIFORD project 'Towards a strategy for optimal vitamin D fortification', financed by the EU, the 5th Framework Programme (QLK1-CT-2000-00 623).

The work was carried out from the Danish Institute for Food and Veterinary Research (now National Food Institute, Technical University of Denmark), Department of Nutrition, Mørkhøj Bygade 19, DK-2860 Søborg, Denmark.

R. A. collected the data, wrote the manuscript and undertook the statistical analyses with L. T. S., C. M. and L. O. providing advice. R. A., C. B., K. D. C., C. L.-A., C. M. and L. O. designed the study. J. J. undertook the measurements of S-25OHD, K. D. C. the measurements of bone turnover markers, and C. L.-A. the measurements of iPTH. All contributed to the manuscript. None of the authors had conflicts of interest.

\section{References}

1. Andersen R, Mølgaard C, Skovgaard LT, Brot C, Cashman KD, Jakobsen J, Lamberg-Allardt C \& Ovesen L (2007) Pakistani immigrant children and adults in Denmark have severely low vitamin D status. Eur J Clin Nutr (epublication ahead of print version 18 April 2007)

2. Brunvand L \& Haug E (1993) Vitamin D deficiency amongst Pakistani women in Oslo. Acta Obestet Gynecol Scand 72, 264-268.

3. Falch JA \& Steihaug S (2000) Vitamin D deficiency in Pakistani premenopausal women living in Norway is not associated with evidence of reduced skeletal strength. Scand J Clin Lab Invest 60, $103-110$.

4. Holvik K, Meyer HE, Haug E \& Brunvand L (2005) Prevalence and predictors of vitamin D deficiency in five immigrant groups living in Oslo, Norway: the Oslo Immigrant Health Study. Eur J Clin Nutr 59, 57-63.

5. Meyer HE, Falch JA, Søgaard AJ \& Haug E (2004) Vitamin D deficiency and secondary hyperparathyroidism and the association with bone mineral density in persons with Pakistani and Norwegian background living in Oslo, Norway, The Oslo Health Study. Bone 35, 412-417.

6. Roy DK, Berry JL, Pye SR, Adams JE, Swarbrick CM, King Y, Silman AJ \& O'Neill TW (2007) Vitamin D status and bone mass in UK South Asian women. Bone 40, 200-204.

7. Chapuy M-C, Arlot ME, Duboeuf F, Brun J, Crouzet B, Arnaud S, Delmas PD \& Meunier PJ (1992) Vitamin $\mathrm{D}_{3}$ and calcium to prevent hip fractures in elderly women. $N$ Engl J Med 327, $1637-1642$.

8. Dawson-Hughes B, Harris SS, Krall EA \& Dallal GE (1997) Effect of calcium and vitamin D supplementation on bone density in men and women 65 years of age or older. $N$ Engl $J$ Med 337, 670-676.

9. Jackson RD, LaCroix AZ, Gass M, et al. (2006) Calcium plus vitamin D supplementation and the risk of fractures. $N$ Engl $J$ Med 354, 669-683.

10. Lips P, Graafmans WC, Ooms ME, Bezemer PD \& Bouter LM (1996) Vitamin D supplementation and fracture incidence in elderly persons. A randomized, placebo-controlled clinical trial. Ann Intern Med 124, 400-406.

11. Meyer HE, Smedshaug GB, Kvaavik E, Falch JA, Tverdal A \& Pedersen JI (2002) Can vitamin D supplementation reduce the risk of fracture in the elderly? A randomized controlled trial. $J$ Bone Min Res 17, 709-715.

12. Porthouse J, Cockayne S, King C, et al. (2005) Randomised controlled trial of calcium and supplementation with cholecalciferol (vitamin $\mathrm{D}_{3}$ ) for prevention of fractures in primary care. $\mathrm{Br}$ Med $J$ 330, 1003.

13. Grant AM, Anderson FH, Avenell A, et al. (2005) Oral vitamin $\mathrm{D}_{3}$ and calcium for secondary prevention of low-trauma fractures in elderly people (Randomised Evaluation of Calcium Or vitamin D, RECORD): a randomised placebo-controlled trial. Lancet 365, 1621-1628.

14. Trivedi DP, Doll R \& Khaw KT (2003) Effect of four monthly oral vitamin $\mathrm{D}_{3}$ (cholecalciferol) supplementation on fractures and mortality in men and women living in the community: randomised double blind controlled trial. Br Med J 326, 469-474.

15. Bischoff-Ferrari HA, Willett WC, Wong JB, Giovannucci E, Dietrich T \& Dawson-Hughes B (2005) Fracture prevention with vitamin D supplementation: a meta-analysis of randomized controlled trials. JAMA 293, 2257-2264.

16. Avenell A, Gillespie WJ, Gillespie LD \& O'Connell DL (2005) Vitamin $\mathrm{D}$ and vitamin $\mathrm{D}$ analogues for preventing fractures associated with involutional and post-menopausal osteoporosis. Cochrane Database Syst Rev, Issue 3, CD000227. http://mrw.interscience. wiley.com/cochrane/clsysrev/articles/CD000227/frame.html

17. Düppe H, Gärdsell P \& Johnell O (1997) A single bone density measurement can predict fractures over 25 years. Calcif Tissue Int 60, 171-174.

18. Marshall D, Johnell O \& Wedel H (1996) Meta-analysis of how well measures of bone mineral density predict occurrence of osteoporotic fractures. Br Med J 312, 1254-1259.

19. Dawson-Hughes B, Dallal GE, Krall EA, Harris S, Sokoll LJ \& Falconer G (1991) Effect of vitamin D supplementation on wintertime and overall bone loss in healthy postmenopausal women. Ann Int Med 115, 505-512.

20. Dawson-Hughes B, Harris SS, Krall EA, Dallal GE, Falconer G \& Green CL (1995) Rates of bone loss in postmenopausal women randomly assigned to one of two dosages of vitamin D. Am J Clin Nutr 61, 1140-1145.

21. Ooms ME, Roos JC, Bezemer D, van der Vijgh WJF, Bouter LM \& Lips P (1995) Prevention of bone loss by vitamin D supplementation in elderly women: a randomized double-blind trial. J Clin Endocrin Metab 80, 1050-1058.

22. Glerup H, Mikkelsen K, Poulsen L, Hass E, Overbeck S, Andersen H, Charles P \& Eriksen EF (2000) Hypovitaminosis D myopathy without biochemical signs of osteomalacic bone involvement. Calcif Tissue Int 66, 419-424.

23. van der Heyden JJC, Verrips A, ter Laak HJ, Otten B \& Fiselier $\mathrm{T}$ (2004) Hypovitaminosis D-related myopathy in immigrant teenagers. Neuropediatrics 35, 290-292.

24. Stephens WP, Berry JL, Klimiuk PS \& Mawer EB (1981) Annual high-dose vitamin D prophylaxis in Asian immigrants. Lancet ii, 1199-1201.

25. Pietrek J, Preece MA, Windo J, O'Riordan JL, Dunnigan MG, McIntosh WB \& Ford JA (1976) Prevention of vitamin-D deficiency in Asians. Lancet i, 1145-1148.

26. Henderson JB, Dunnigan MG, McIntosh WB, Abdul Motaal A \& Hole D (1990) Asian osteomalacia is determined by dietary factors when exposure to ultraviolet radiation is restricted: a risk factor model. $Q J$ Med 76, 923-933.

27. Dunnigan MG, Glekin BM, Henderson JB, McIntosh WB, Sumner D \& Sutherland GR (1985) Prevention of rickets in Asian children: assessment of the Glasgow campaign. $\mathrm{Br}$ Med $J$ (Clin Res Ed) 291, 239-242.

28. Dunnigan MG, McIntosh WB, Sutherland GR, Gardee R, Glekin B, Ford JA \& Robertson I (1981) Policy for prevention of Asian rickets in Britain: a preliminary assessment of the Glasgow rickets campaign. $\mathrm{Br}$ Med J (Clin Res Ed) 282, 357-360.

29. Dunnigan MG, Paton JPJ, Haase S, McNicol GW, Gardner MD \& Smith CM (1962) Late rickets and osteomalacia in the Pakistani community in Glasgow. Scot Med J 7, 159-167. 
30. Aloia JF, Talwar SA, Pollack S \& Yeh J (2005) A randomized controlled trial of vitamin $\mathrm{D}_{3}$ supplementation in African American women. Arch Intern Med 165, 1618-1623.

31. Statistics Denmark (2005) BEF3: Population by area, age, sex, country of origin and citizenship (1980-2005). http://www. statistikbanken.dk/statbank5a/default.asp?w=1024 (accessed January 2005).

32. Andersen NL, Fagt S \& Groth MV (1996) Danskernes Kostvaner 1995 (Dietary Habits of Danes 1995), Publication no. 235. Søborg, Denmark: Levnedsmiddelstyrelsen.

33. Andersen R, Mølgaard C, Skovgaard LT, et al. (2005) Teenage girls and elderly women living in northern Europe have low winter vitamin D status. Eur J Clin Nutr 59, 533-541.

34. Christensen T (2001) Outline of GIES: General Intake Estimation System. In Fourth International Food Data Conference: New Trends in the Management and Uses of Food Databases, 24-26 August 2001, poster P-I-B-06. Bratislava, Slovakia: Ministry of Agriculture of the Slovak Republic.

35. Dawson-Hughes B, Heaney RP, Holick MF, Lips P, Meunier PJ \& Vieth R (2005) Estimates of optimal vitamin D status. Osteoporos Int 16, 713-716.

36. Binkley N, Krueger D, Cowgill CS, Plum L, Lake E, Hansen KE, DeLuca HF \& Drezner MK (2004) Assay variation confounds the diagnosis of hypovitaminosis D: a call for standardization. J Clin Endocrin Metab 89, 3152-3157.
37. Carter GD, Carter R, Jones J \& Berry J (2004) How accurate are assays for 25-hydroxyvitamin D? Data from the international vitamin D external quality assessment scheme. Clin Chem 50, 2195-2197.

38. Hollis BW (2004) The determination of circulating 25-hydroxyvitamin D: no easy task. J Clin Endocrin Metab 89, 3149-3151.

39. Dawson-Hughes B (2004) Racial/ethnic considerations in making recommendations for vitamin D for adult and elderly men and women. Am J Clin Nutr 80, Suppl. 6, 1763S-1766S.

40. Alver K, Meyer HE, Falch JA \& Sogaard AJ (2004) Bone mineral density in ethnic Norwegians and Pakistani immigrants. J Bone Min Res 19, S159.

41. Holvik K, Meyer HE, Falch JA, Søgaard AJ \& Haug E (2004) The Oslo Health Study: biochemical markers of bone turnover and their relation to parathyroid hormone levels in persons of Pakistani and Norwegian origin living in Oslo. J Bone Min Res 19, S167.

42. Holick MF (2004) Sunlight and vitamin D for bone health and prevention of autoimmune diseases, cancers, and cardiovascular disease. Am J Clin Nutr 80, Suppl. 6, 1678S-1688S.

43. Widdowson EM, Elton GAH, Exton-Smith AN, Oppé TE, Truswell AS \& Waterlow JC (1980) Rickets and Osteomalacia. Report of the Working Party on Fortificaiton of Food with Vitamin D. Committee on Medical Aspects of Food Policy. Report on Health and Social Subjects no. 19. London: Her Majesty's Stationery Office. 